\title{
Radiometric properties of virgin and cultivated soil around the Shazand Refinery Complex in Iran
}

\author{
M. Mohebian and R. Pourimani ${ }^{*}$
}

\author{
Department Department of Physics, Faculty of Science, Arak University, Arak 38156, Iran
}

\begin{abstract}
- Original article

\section{*Corresponding authors: \\ Reza Pourimani, Ph.D., \\ E-mail:}

r-pourimani@araku.ac.ir

Revised: November 2019

Accepted: January 2020

Int. J. Radiat. Res., October 2020; 18(4): $723-732$

DOI: 10.18869 /acadpub.ijrr.18.4.723

Background: One of the main sources of exposure to radiation is terrestrial radionuclides in the environment. These radioisotopes are present in the Earth's crust and can be increased by human activity such as mining of coal, oil, and minerals. Materials and Methods: In this study, 39 soil samples including virgin and cultivated were collected from around of the Shazand Refinery Complex(SRC) using a template and experimental method. The gamma spectrometry method was used to measure the specific activity of the ${ }^{226} \mathrm{Ra},{ }^{232} \mathrm{Th},{ }^{40} \mathrm{~K}$ and ${ }^{137} \mathrm{Cs}$ radionuclides. Results: The average concentrations of ${ }^{226} \mathrm{Ra},{ }^{232} \mathrm{Th},{ }^{40} \mathrm{~K}$ and ${ }^{137} \mathrm{Cs}$ in the cultivated (virgin) soil samples were $21.95 \pm$ 0.27 (23.99 \pm 0.37$), 25.37 \pm 0.29$ (31.74 \pm 0.38$), 416.72 \pm 1.88$ (461.09 \pm 2.68$)$ and $5.13 \pm 0.08$ (5.51 \pm 0.14$)$ in $\mathrm{Bq} \mathrm{kg}^{-1}$. Excess lifetime cancer risk (ELCR) was obtained for cultivated (virgin) soil as $0.19 \times 10^{-3}\left(0.22 \times 10^{-3}\right)$, which is close to the world average $\left(0.29 \times 10^{-3}\right)$ and lowers than the maximum acceptable value $\left(10^{-3}\right)$. Conclusion: The specific activities of natural radionuclides were in the global range and are lower than the maximum allowable value. The distribution map of ${ }^{226} \mathrm{Ra}$ and ${ }^{137} \mathrm{Cs}$ indicated some part of ${ }^{226} \mathrm{Ra}$, distributed as fly ash from a chimney, caused by the incineration of refinery waste. The radiological parameters calculated for both types of soil were lower than the maximum admissible values, and therefore there is no radiological hazard for people living in this area.
\end{abstract}

Keywords: Dosage, radionuclides, radiation, soil, pollution.

\section{INTRODUCTION}

A high percentage of total environmental irradiation results from natural radiation (1). In particular, natural radioactive nuclei in soil, water and air are responsible for human exposure to radiation (2). Natural radioactive nuclei easily move in the human environment and their mobility results from their geochemical properties (3). Radionuclides (uranium, thorium series and potassium) are found naturally in soil, stones and water. The average amount of uranium and thorium in the earth's crust is estimated to be $2.7 \mathrm{mg} \mathrm{kg}^{-1}$ and $9.6 \mathrm{mg} \mathrm{kg}^{-1}$. Potassium is one of the main components of the earth's crust, creating 2.8 percent of the shell composition (4). Human activities, such as mining (ore crushing), metal extraction processes, nuclear fuel production, and end-of-fuel products, are transmitted to the environment to a significant extent by radioactive nuclei (1). In recent years, concentrations of natural radionuclide in various petroleum and oils have been measured in many countries $(5,6)$. Part of the radionuclides in the oil is burned during the refinery process along with the waste distillation tower and dispersed through the chimneys in the air, and after cooling; the ash contains radioactive nuclei, falls on the surrounding soil and increases the radiation level. It depends primarily on the ambient temperature, humidity of air and wind direction. Man-made radionuclides are produced from nuclear industrial activities, nuclear power plant accidents, or military uses. Radionuclides produced from nuclear activities 
are dispersed in ecosystems of the environment depending on their physicochemical properties and conditions prevailing in the environment(1). According to the report by United Nations Scientific Committee on the effect of Atomic Radiation, the atmospheric nuclear test of nuclear weapons from 1945 to 1980 and nuclear accidents such as the Chernobyl (1986) nuclear reactor are the main sources of environmental pollution by ${ }^{137} \mathrm{Cs}$ and ${ }^{90} \mathrm{Sr}$ radionuclides. The accident in Chernobyl released $3.8 \times 10^{16} \mathrm{~Bq}$ of radionuclide ${ }^{137} \mathrm{Cs}$ in atmosphere (1). Every nuclear explosion causes the uncontrolled release of a significant amount of radioactive materials into the atmosphere, which are gradually stored all over the world. ${ }^{90} \mathrm{Sr}$ with a half-life of 28.78 years is considered as an important health hazard because it replaces calcium in the bone. Among the class of artificial isotopes released as fission products, ${ }^{137} \mathrm{Cs}$ is the most prominent isotope detected by its gamma radiation on the earth's surface ${ }^{(7)} .{ }^{137} \mathrm{Cs}$ penetrates the soil through water step by step and can enter to groundwater. This cesium remains for long time in the upper layers of the soil and joins the soil particles. The aim of the study was to investigate the impact of radioactive pollutant outlets from refinery chimneys on cultivated and virgin land around these complexes. Also in this work, the concentration of radionuclides in cultivated and virgin soil was measured, as well as to assess radiological parameters such as the absorbed dose in the air, the annual effective dose (internal and external), internal and external hazard indices and the gamma index from the point of impact on public health living in these areas.

\section{MATERIALS AND METHODS}

\section{Introducing areas under study}

Shazand refining and petrochemical plants are located in the city of Shazand in Markazi province in Iran at kilometer 22 of the Arak-Khoramabad road and have been built on an area of 523 hectares. One of the largest producers of oil components, polymers and chemical products, as well as one of the most important projects in Iran was built in 1992(8). There are several chimneys that spread fly ash from combustion to the environment.

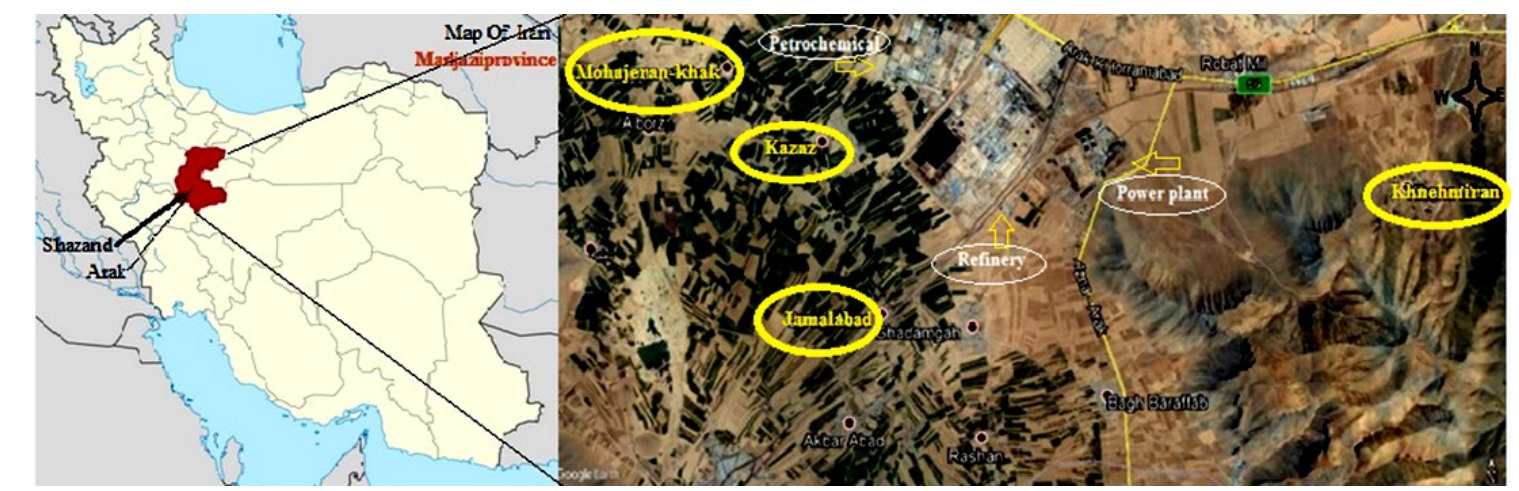

Figure 1. Sampling location map showing study area, Khanemiran, Mahajeran-khak, Kazaz and Jamalabad around of SRC.

\section{Sampling and sample preparation}

In this study, 39 soil samples were collected from virgin and cultivated areas in Kazaz, Mohajeran, Jamal Abad and Khane-Miran in fields in the Markazi province of Iran to measure the concentration of radionuclides. 9, 8, 12 and 10 samples were prepared respectively from these areas. Figure 1 shows the location of studied area. A random and experimental sampling method was used to collect samples. Of all samples, stones, roots and waste were removed. After the drying and milling process, the samples were sieved by a $0.508 \mathrm{~mm}$ pore size sieve and prepared for each homogeneous sample. Samples packed in cylindrical containers, weighing 300 grams and sealed with 
silicone glue to prevent escape of radon gas (creating an equilibrium between ${ }^{226} \mathrm{Ra}$ and their daughters in the sample ${ }^{(9)}$.

\section{Gamma spectrometry and analysis}

A high purity germanium (HPGe) P-type coaxial detector (GCD30195BSI model manufactured by Baltic Scientific Instrument LTD, 005- Latvia) was used to measure gamma spectra of soil samples. The energy resolution for $1332 \mathrm{keV}\left({ }^{60} \mathrm{Co}\right)$ and the relative efficiency of detector were $1.95 \mathrm{keV}$ and $30 \%$ respectively. Detector and preamplifier were shielded in a chamber of three layers composed of $10 \mathrm{~cm}$ thick lead, $1.5 \mathrm{~mm}$ thick cadmium and $2 \mathrm{~mm}$ thick by copper to reduce background radiation (10). Multi-Channel Analyzer (8 k MCA) and with other electronic accessories were in the bin set and connected to PC. Initially the detector was calibrated so that the energy of each peak should be in accordance with corresponding channel number. The energy calibration was performed using ${ }^{241} \mathrm{Am},{ }^{152} \mathrm{Eu}$ and ${ }^{137} \mathrm{Cs}$ sources. To register the spectrum of each sample, the packed soil samples were placed face to face of detector in center of shield chamber individually. The time of spectrometry depends on the efficiency of the detector (vice versa) and it must be long enough for the photo peaks to have a Gaussian shape. The soil samples spectrum was registered for 86400 seconds and recorded by the Lsrmbsi software (Baltic Scientific Instrument LTD, 005-Latvia). Calibration of the system was carried out using a standard soil source, which contained ${ }^{152} \mathrm{Eu},{ }^{241} \mathrm{Am},{ }^{133} \mathrm{Ba}$ and ${ }^{137} \mathrm{Cs}$. Gamma Ray reference material from uranium, thorium and potassium (RGU-1, RGTh-1, RGK-1), which was prepared by the International Atomic Energy Agency (IAEA), was used to control the quality of efficiency calibration in the energy range 58.78 - 2478, $09 \mathrm{keV}$. The measurement results of reference material are shown in table 1. To evaluate the uncertainty of measurement amount of reference material, calculated Z-score value (11)

The z-score was calculated using equation 1 :

$$
Z=\frac{e-c}{\sqrt{u_{e}^{2}+u_{c}^{2}}}
$$

Where; e is the experimental result that has been measured, $c$ is the certified value reported by the IAEA, $u_{e}, u_{c}$ are the uncertainties of the measured and reported values respectively. The acceptable $\mathbf{Z}$ value for the measured activity should be $|\mathrm{Z}|<2$. Standard deviations higher or lower than the certified value are determined by z-score (11).

Table 1. Certificated and measured values for reference material IAEA and z-score values.

\begin{tabular}{|c|c|c|c|c|c|}
\hline $\begin{array}{c}\text { Reference } \\
\text { material }\end{array}$ & $\begin{array}{c}\text { Contains } \\
\text { elements }\end{array}$ & $\begin{array}{c}\text { certified } \\
\text { value } \\
\left(\mathrm{Bq} \mathrm{kg}^{-1}\right)\end{array}$ & $\begin{array}{l}\text { Average } \\
\text { activity } \\
\left(\mathrm{Bq} \mathrm{kg}^{-1}\right)\end{array}$ & $\begin{array}{c}\text { measured } \\
\text { activity } \\
\left(\mathrm{Bq} \mathrm{kg}^{-1}\right)\end{array}$ & $\begin{array}{c}\mathrm{Z} \text { - } \\
\text { score }\end{array}$ \\
\hline RGU-1 & $\begin{array}{c}7.09 \% \text { U } \\
\text { (uranium } \\
\text { ore) }\end{array}$ & $\begin{array}{c}4910- \\
4970\end{array}$ & $\begin{array}{c}4940 \pm \\
30\end{array}$ & $\begin{array}{c}4979.54 \pm \\
30.78\end{array}$ & 0.92 \\
\hline RGTh-1 & $\begin{array}{c}2.89 \% \mathrm{Th} \\
\text { (thorium } \\
\text { ore) }\end{array}$ & $\begin{array}{l}3160- \\
3340\end{array}$ & $\begin{array}{c}3250 \pm \\
90\end{array}$ & $\begin{array}{c}3206.37 \pm \\
21.82\end{array}$ & -0.4 \\
\hline RGUK-1 & \begin{tabular}{|c|}
$99.8 \%$ \\
(potassium \\
sulphate)
\end{tabular} & $\begin{array}{c}13600- \\
14400\end{array}$ & $\begin{array}{c}14000 \pm \\
400\end{array}$ & $\begin{array}{c}14089.47 \\
\pm 83.82\end{array}$ & 0.22 \\
\hline
\end{tabular}

The Gamma vision 32 software (manufacture by E\&G Ortec company Tennessee 37831 USA) were used for analysis spectra. The concentration of radionuclides were determined in soil samples using the equation 2 (12):

$\operatorname{Activity}\left(B q \mathrm{~kg}^{-1}\right)=\frac{\mathrm{N}-\mathrm{B}}{\mathrm{T} \times \mathrm{p} \times \mathrm{E \times C}}$

Where; $T$ is the counting time (s), $\rho$ is the gamma emission probability, $\varepsilon$ is the absolute detector efficiency in the specified gamma energy and $\omega$ sample mass $(\mathrm{kg}), \mathrm{N}$ number of the desired peak, and $\mathrm{B}$ is the background spectrum counting at the peak located at the same time. The average of specific activity and its uncertainty in all of soil samples were calculated by equations 3 and 4:

$$
\begin{aligned}
& \text { A(average })=\frac{\sum_{i=1}^{g 9} \frac{\mu_{i}}{\sigma_{i}}}{\sum_{i=1}^{g 9} \frac{1}{\sigma_{i}}} \\
& \sigma(\text { average })=\frac{1}{\sqrt[n]{\sum_{i=1}^{g 9} \frac{1}{\sigma_{i}^{2}}}}
\end{aligned}
$$

Where; $\mathrm{A}_{\mathrm{i}}(\mathrm{Bq} \mathrm{kg}-1)$ and $\sigma_{\mathrm{i}}$ are specific activity 
and its uncertainty, respectively (13). The minimum detectable activity (MDA) was also determined from the background radiation spectrum using equation 5 (14):

$$
\operatorname{MDA}\left(\mathrm{Bq} \mathrm{kg}^{-1}\right)=\frac{2.76+(4.6 \times \sqrt{\mathrm{B}})}{\operatorname{T\times p\times 2\times \omega }}
$$

The minimum detectable activity (MDA) for ${ }^{137} \mathrm{Cs}$ was found as $1.43 \mathrm{Bqkg}^{-1}$. The specific activity of the ${ }^{226} \mathrm{Ra}$ was determined using the gamma lines $295.2 \mathrm{keV}$ and $351.9 \mathrm{keV}$ for ${ }^{214} \mathrm{~Pb}$ and $609.3,1120.3$ and 1764.3 for ${ }^{214} \mathrm{Bi}$. For ${ }^{232} \mathrm{Th}$, the specific activity was determined using the gamma lines $338.40 \mathrm{keV}$ and $911.07 \mathrm{keV}$ for ${ }^{228} \mathrm{Ac}$. In the case of ${ }^{40} \mathrm{~K}$ and ${ }^{137} \mathrm{Cs}$, the specific activities were evaluated by their individual gamma lines of $1460.75 \mathrm{keV}$ and $661.7 \mathrm{keV}$, respectively (12). The worldwide average values of specific activity ${ }^{226} \mathrm{Ra},{ }^{232} \mathrm{Th}$ and ${ }^{40} \mathrm{~K}$ are 30,35 and $400 \mathrm{~Bq} \mathrm{~kg}^{-1}$ respectively(1).

\section{Radiological parameters \\ Radium equivalent activities ( $\left(\mathrm{R}_{e q}\right)$}

$98.9 \%$ of the radiological effects of the uranium series come from ${ }^{226} \mathrm{Ra}$ and its daughters (12). Therefore, to determine the total natural radioactivity of the soil and determine the level of environmental safety of radiation and its comparison with the maximum permitted content of radionuclides, the concept of radium equivalent is used. This concept is based on the fact that $10 \mathrm{~Bq} \mathrm{~kg}^{-1}$ of ${ }^{226} \mathrm{Ra}, 7 \mathrm{~Bq}$ $\mathrm{kg}^{-1}$ of ${ }^{232} \mathrm{Th}$ and $130 \mathrm{~Bq} \mathrm{~kg}-1$ of ${ }^{40} \mathrm{~K}$ gives the same dose of gamma radiation, respectively. The radium equivalent activity can be calculated using equation $6^{(1)}$ :

$\mathrm{Ra}_{\mathrm{eq}}=\mathrm{A}_{\mathrm{Ra}}+1.43 \mathrm{~A}_{\mathrm{Th}}+0.077 \mathrm{~A}_{\mathrm{K}}$

For building material this quantity should be less than $370 \mathrm{~Bq} \mathrm{~kg}^{-1}(15)$.

\section{Absorbed dose rate (D)}

Absorbed dose rate in air at height of one meter above ground (D) due to gamma rays emitted from ${ }^{226} \mathrm{Ra},{ }^{232} \mathrm{Th}$ and ${ }^{40} \mathrm{~K}$ radioactive nuclei in soil is calculated using equation $7^{(1)}$ :

$\mathrm{D}\left(\right.$ nGy h$\left.^{-1}\right)=0.427 \times \mathrm{A}_{\mathrm{Ra}}+0.662_{\mathrm{Th}}+0.0432 \times \mathrm{A}_{\mathrm{K}}$
Dose rate absorption for the anthropogenic radionuclide ${ }^{137} \mathrm{Cs}$, can be calculated using equation 8 (16):

$\mathrm{D}_{\mathrm{Cs}}^{\circ}=0.03 \times \mathrm{A}_{\mathrm{Cs}}$

Where; $\mathrm{A}_{\mathrm{Cs}}$ is the specific activity of the ${ }^{137} \mathrm{Cs}$ and 0.03 is the dose conversion factor for the ${ }^{137} \mathrm{Cs}$ activity per $\mathrm{Bq} \mathrm{kg}-1$ so dose rate is expressed in the units of nGy $\mathrm{h}^{-1}$.

Internal and external hazard Indices $\left(H_{i n}, H_{e x}\right)$

The internal hazard index refers to the carcinogen inhalation of radon gas, and to limit this risk, the maximum permitted radium activity would be halved. The external exposure to gamma rays in the study area is called external hazard index and equations 9 and 10 are used to calculate these indices, respectively (1):

$H_{\text {in }}=\frac{A_{R a}}{185}+\frac{A_{T h}}{259}+\frac{A_{K}}{4810} \leq 1$

$H_{e x}=\frac{A_{R a}}{370}+\frac{A_{T h}}{259}+\frac{A_{K}}{4810} \leq 1$

It was established that the maximum Hex value should not exceed 1 , which corresponds to the maximum permissible $\mathrm{Ra}_{\mathrm{eq}}$ value for building materials equal to $370 \mathrm{Bqkg}^{-1}$ (15).

\section{Gamma index $\left(I_{\gamma}\right)$}

$\mathrm{I}_{\gamma}$ is used to evaluate the radiation of gamma hazard which associated with the natural radionuclide in studied soil samples. It was calculated by equation 11 :

$I_{Y}=\frac{A_{R a}}{150}+\frac{A_{T h}}{100}+\frac{A_{K}}{1500}$

Where; $A_{R a}, A_{T h}, A_{K}$ and $A_{C s}$ in equations 6 to 11 are specific activities of ${ }^{226} \mathrm{Ra},{ }^{232} \mathrm{Th},{ }^{40} \mathrm{~K}$ and ${ }^{137} \mathrm{Cs}$ in $\mathrm{Bqkg}^{-1}$ (1). It is a test tool for the identification of the material that may pose a health risk when it is used in the construction of buildings (17).

\section{Annual effective dose equivalent (AEDE)}

The effective dose equivalent to the absorption of gamma radiation throughout the 
year by an adult person depends on the time of exposure. According to a report prepared by UNSCEAR (2008), it is assumed that the urban population spends $80 \%$ of the time indoors, and spends twenty percent of their time outside. Therefore, the annual effective dose received by adult person can be estimated by using equation 12:

$\operatorname{AEDE}\left(\mathrm{mSv} \mathrm{y}^{-1}\right)=\mathrm{Q} \times \mathrm{T} \times \mathrm{W} \times \mathrm{D} \times 10^{-6}$

Where; the AEDE represents annual effective dose equivalent in $\mathrm{mSvy}^{-1}, \mathrm{Q}$ is the conversion factor as $0.7 \mathrm{SvGy}^{-1}, \mathrm{~T}$ is the time in hours for one year, i.e. 8760 hours, $D$ is the dose rate in nGyh $^{-1}$ and $\mathrm{W}$ is the occupancy factor for outdoor and indoor as 0.20 and 0.80 respectively ${ }^{(1)}$.

\section{Excess lifetime cancer risk (ELCR)}

ELCR is an indicator that depends on the average annual effective dose received by adult person which is caused by gamma emissions from the ground. This parameter is calculated using equation 13 :

\section{$\mathrm{ELCR}=\mathrm{AEDE} \times \mathrm{LT} \times \mathrm{RF}$}

Where; AEDE is annual effective dose rate, LT is average life of time with value 70 years and $\mathrm{RF}$ is risk factor in $\mathrm{Sv}^{-1}$. For people, the International Commission on Radiological Protection (ICRP 60) established the values of $\mathrm{RF}$ as $0.05 \mathrm{~Sv}^{-1}(18)$.

\section{RESULTS}

The result of specific activities of natural and ${ }^{137} \mathrm{Cs}$ radionuclides measured for 39 samples included cultivated and virgin soil is presented in table 2. Also the results of the calculation of radiological parameters for cultivated and virgin soil samples presented in tables 3, 4 and 5 .

Table 2. The specific activities of natural radionuclides and ${ }^{137} \mathrm{Cs}$ in $\mathrm{Bqkg}^{-1}$. in cultivated and virgin soil samples.

\begin{tabular}{|c|c|c|c|c|c|c|c|c|c|}
\hline \multirow{2}{*}{$\begin{array}{c}\text { Sample } \\
\text { code }\end{array}$} & \multicolumn{4}{|c|}{ specific activities of radionuclides $\left(\mathrm{Bq} \mathrm{kg}^{-1}\right)$} & \multirow{2}{*}{$\begin{array}{c}\text { Sample } \\
\text { code }\end{array}$} & \multicolumn{4}{|c|}{ specific activities of radionuclides $\left(\mathrm{Bq} \mathrm{kg}^{-1}\right)$} \\
\hline & ${ }^{226} \mathrm{Ra}$ & ${ }^{232} \mathrm{Th}$ & ${ }^{40} \mathrm{~K}$ & ${ }^{137} \mathrm{Cs}$ & & ${ }^{226} \mathrm{Ra}$ & ${ }^{232} \mathrm{Th}$ & \begin{tabular}{l|l}
${ }^{40} \mathbf{K}$ \\
\end{tabular} & ${ }^{137}$ Cs \\
\hline \multicolumn{5}{|c|}{ Cultivated soil samples } & \multicolumn{5}{|c|}{ Virgin soil samples } \\
\hline CS1 & $9.98 \pm 1.52$ & $23.44 \pm 1.80$ & $403.51 \pm$ & $4 \pm 0.43$ & & & $27.73 \pm 1.47$ & $523.19 \pm 1$ & $66 \pm 0.95$ \\
\hline CS2 & & & & & & & & & \\
\hline CS3 & & & & $5 \pm 0.68$ & & & & & 43 \\
\hline CS4 & & & & $0 \pm 0$. & & & & & .43 \\
\hline CS5 & 31 & 3 & & $0 \pm 0.42$ & & 43 & & & 1.43 \\
\hline CS6 & 3 & & & $4 \pm 0.39$ & & 83 & & & $8 \pm 0.69$ \\
\hline C & & & & \pm 0.59 & & & & & $4 \pm 0.39$ \\
\hline CS8 & & 0 & & $6 \pm 0.76$ & & & & & \pm 0.43 \\
\hline CS9 & & & & $0 \pm 0.93$ & S9 & $94 \pm 2.09$ & & & $0 \pm 0.42$ \\
\hline CS10 & 66 & 1.40 & 17.16 & $1.04 \pm 0.38$ & 510 & \pm 1.35 & 1.74 & & $6 \pm 0.79$ \\
\hline CS11 & & & & $<1.43$ & & & & & \pm 0.43 \\
\hline CS12 & & & & $3.89 \pm 0.4$ & & & & & $1 \pm 0.46$ \\
\hline & & $20.00-1$. & & $2.92 \pm 0.39$ & & & & & $7 \pm 0.42$ \\
\hline & & & & $2.62 \pm 0.42$ & & & & & $4.42 \pm 0.71$ \\
\hline & & & & $5.98 \pm 0.81$ & & & & & $<1.43$ \\
\hline & & & & $3.21 \pm 0.40$ & & & & & $3.47 \pm 0.43$ \\
\hline CS17 & $19.84 \pm 2.34$ & $6.77 \pm 2.22$ & $519.64 \pm 12.2$ & $4.26 \pm 0.41$ & & $30.05 \pm 1.45$ & & & $17.78 \pm 0.82$ \\
\hline CS18 & $18.61 \pm$ & $8.85 \pm 1.33$ & $548.11 \pm 17.15$ & $<1.43$ & VS18 & $31.36 \pm 2.08$ & $36.27 \pm 1.76$ & 13.85 & $6.16 \pm 0.73$ \\
\hline \multirow[t]{2}{*}{ CS19 } & $23.32 \pm 2.11$ & $23.13 \pm 1.64$ & $430.67 \pm 13.81$ & $9.77 \pm 0.48$ & VS19 & $14.72 \pm 1.27$ & & & $4.42 \pm 0.71$ \\
\hline & & & & & & $29.61 \pm 1.83$ & & $565.02 \pm 18.23$ & $10.12 \pm 0.92$ \\
\hline & $20.81 \pm 0.37$ & $26.99 \pm 0.38$ & $430.43 \pm 2.74$ & $4.26 \pm 0.14$ & mean & $23.99 \pm 0.37$ & $31.74 \pm 0.38$ & $461.09 \pm 2.68$ & $5.51 \pm 0.14$ \\
\hline
\end{tabular}


Table 3. Radiological parameters of soil samples.

\begin{tabular}{|c|c|c|c|c|c|c|c|c|c|}
\hline $\begin{array}{c}\text { Sample } \\
\text { code }\end{array}$ & $\mathbf{R a}_{\text {eq }}$ & $\mathbf{H}_{\text {in }}$ & $\mathbf{H}_{\text {ex }}$ & $\mathbf{I}_{v}$ & $\begin{array}{c}\text { Sample } \\
\text { code }\end{array}$ & $\mathbf{R a}_{\text {eq }}$ & $\mathbf{H}_{\text {in }}$ & $\mathbf{H}_{\text {ex }}$ & $\mathbf{I}_{v}$ \\
\hline & \multicolumn{3}{|c|}{ Cultivated soil samples } & \multicolumn{4}{|c|}{ Virgin soil samples } \\
\hline CS1 & 84.57 & 0.28 & 0.23 & 0.63 & VS1 & 103.6 & 0.33 & 0.28 & 0.78 \\
\hline CS2 & 90.15 & 0.29 & 0.24 & 0.67 & VS2 & 77.74 & 0.25 & 0.21 & 0.58 \\
\hline CS3 & 99.62 & 0.32 & 0.27 & 0.74 & VS3 & 98.29 & 0.33 & 0.27 & 0.73 \\
\hline CS4 & 94.52 & 0.32 & 0.26 & 0.7 & VS4 & 92.33 & 0.31 & 0.25 & 0.69 \\
\hline CS5 & 97.06 & 0.32 & 0.26 & 0.72 & VS5 & 83.71 & 0.27 & 0.23 & 0.62 \\
\hline CS6 & 51.57 & 0.17 & 0.14 & 0.39 & VS6 & 105.7 & 0.34 & 0.29 & 0.04 \\
\hline CS7 & 93.25 & 0.3 & 0.25 & 0.7 & VS7 & 105 & 0.34 & 0.28 & 0.03 \\
\hline CS8 & 119.8 & 0.39 & 0.32 & 0.89 & VS8 & 117.9 & 0.38 & 0.32 & 0.88 \\
\hline CS9 & 66.78 & 0.22 & 0.18 & 0.03 & VS9 & 121.6 & 0.39 & 0.33 & 0.9 \\
\hline CS10 & 109.8 & 0.35 & 0.3 & 0.83 & VS10 & 134.8 & 0.43 & 0.36 & 1 \\
\hline CS11 & 67.9 & 0.22 & 0.18 & 0.51 & VS11 & 112.4 & 0.37 & 0.3 & 0.83 \\
\hline CS12 & 102.5 & 0.32 & 0.28 & 0.77 & VS12 & 115.6 & 0.38 & 0.31 & 0.86 \\
\hline CS13 & 86.76 & 0.29 & 0.23 & 0.65 & VS13 & 119.4 & 0.39 & 0.32 & 0.89 \\
\hline CS14 & 100.8 & 0.33 & 0.27 & 0.76 & VS14 & 67.8 & 0.22 & 0.18 & 0.5 \\
\hline CS15 & 117.1 & 0.38 & 0.32 & 0.88 & VS15 & 108.6 & 0.36 & 0.29 & 0.81 \\
\hline CS16 & 98.16 & 0.33 & 0.27 & 0.73 & VS16 & 128 & 0.42 & 0.35 & 0.95 \\
\hline CS17 & 112.4 & 0.35 & 0.3 & 0.84 & VS17 & 126 & 0.41 & 0.34 & 0.94 \\
\hline CS18 & 102.1 & 0.32 & 0.28 & 0.77 & VS18 & 130.3 & 0.43 & 0.35 & 0.97 \\
\hline CS19 & 89.56 & 0.3 & 0.24 & 0.67 & VS19 & 67.8 & 0.22 & 0.18 & 0.5 \\
\hline & & & & & VS20 & 145.1 & 0.46 & 0.39 & 1.07 \\
\hline mean & 93.92 & 0.31 & 0.25 & 0.68 & mean & 108.08 & 0.35 & 0.29 & 0.73 \\
\hline
\end{tabular}

Table 3. Radiological parameters of soil samples.

\begin{tabular}{|c|c|c|c|c|c|c|c|c|}
\hline \multirow{2}{*}{$\begin{array}{l}\text { Sample } \\
\text { code }\end{array}$} & \multicolumn{2}{|c|}{ Dose Rate $\left(n G y h^{-1}\right)$} & \multicolumn{2}{|c|}{$\begin{array}{c}\operatorname{AEDE}_{\text {in }}\left(\mathrm{mSvy}^{-1}\right) \\
\text { For Cs } \times 10^{-3}\end{array}$} & \multicolumn{2}{|c|}{$\begin{array}{c}\text { AEDE }_{\text {out }}\left(\mathrm{mSvy}^{-1}\right) \\
\text { For } \mathrm{Cs} \times 10^{-4}\end{array}$} & \multicolumn{2}{|c|}{$\begin{array}{c}\text { ELCR×10 } \\
\text { For } C s \times 10^{-3}\end{array}$} \\
\hline & ${ }^{226} \mathrm{Ra}^{232}{ }^{232} \mathrm{Th}^{40} \mathrm{~K}$ & ${ }^{137} \mathrm{Cs}$ & ${ }^{226} \mathrm{Ra}^{232}{ }^{232}{ }^{40} \mathrm{~K}$ & ${ }^{137} \mathrm{Cs}$ & ${ }^{226} \mathrm{Ra}^{232}{ }^{232} \mathrm{Th}^{40} \mathrm{~K}$ & ${ }^{137} \mathrm{Cs}$ & ${ }^{226} \mathrm{Ra}^{232}{ }^{232},{ }^{40} \mathrm{~K}$ & ${ }^{137} \mathrm{Cs}$ \\
\hline CS1 & 40.21 & 0.15 & 0.20 & 0.76 & 0.05 & 1.89 & 0.18 & 0.66 \\
\hline CS2 & 42.15 & 0.21 & 0.21 & 0.1 & 0.05 & 2.54 & 0.18 & 0.89 \\
\hline CS3 & 46.89 & 0.12 & 0.23 & 0.58 & 0.06 & 1.45 & 0.21 & 0.51 \\
\hline CS4 & 44.70 & 0.12 & 0.22 & 0.60 & 0.05 & 1.51 & 0.18 & 0.53 \\
\hline CS5 & 46.06 & 0.08 & 0.23 & 0.40 & 0.06 & 0.99 & 0.21 & 0.35 \\
\hline CS6 & 24.49 & 0.06 & 0.12 & 0.31 & 0.03 & 0.79 & 0.11 & 0.28 \\
\hline CS7 & 44.19 & 0.14 & 0.22 & 0.66 & 0.05 & 1.66 & 0.18 & 0.58 \\
\hline CS8 & 56.30 & 0.16 & 0.28 & 0.77 & 0.07 & 1.90 & 0.25 & 0.67 \\
\hline CS9 & 31.64 & 0.03 & 0.16 & 0.14 & 0.04 & 0.34 & 0.14 & 0.12 \\
\hline CS10 & 52.46 & N.D* & 0.26 & N.D* & 0.06 & N.D* & 0.21 & N.D* \\
\hline CS11 & 32.37 & N.D* & 0.16 & N.D* & 0.04 & N.D* & 0.14 & N.D* \\
\hline CS12 & 48.62 & 0.12 & 0.24 & 0.57 & 0.06 & 1.43 & 0.21 & 0.5 \\
\hline CS13 & 41.65 & 0.09 & 0.20 & 0.43 & 0.05 & 1.08 & 0.18 & 0.38 \\
\hline CS14 & 48.04 & 0.08 & 0.23 & 0.38 & 0.06 & 0.96 & 0.21 & 0.34 \\
\hline CS15 & 55.98 & 0.18 & 0.27 & 0.88 & 0.07 & 0.22 & 0.25 & 0.08 \\
\hline CS16 & 46.53 & 0.1 & 0.23 & 0.48 & 0.06 & 1.20 & 0.21 & 0.42 \\
\hline CS17 & 53.04 & 0.13 & 0.26 & 0.62 & 0.07 & 1.57 & 0.25 & 0.55 \\
\hline CS18 & 48.88 & N.D* & 0.24 & N.D* & 0.06 & N.D* & 0.21 & N.D* \\
\hline CS19 & 42.70 & 0.29 & 0.21 & 1.44 & 0.05 & 3.60 & 0.18 & 1.26 \\
\hline mean & 44.57 & 0.11 & 0.22 & 0.57 & 0.05 & 1.22 & 0.19 & 0.43 \\
\hline
\end{tabular}


Table 4. Other radiological parameters of cultivated soil samples.

\begin{tabular}{|c|c|c|c|c|c|c|c|c|}
\hline \multirow[t]{2}{*}{ Sample } & \multicolumn{2}{|c|}{ Dose Rate (nGyh $\left.{ }^{-1}\right)$} & \multicolumn{2}{|c|}{$\begin{array}{c}\operatorname{AEDE}_{\text {in }}\left(\mathrm{mSvy}^{-1}\right) \\
\text { For Cs } \times 10^{-3}\end{array}$} & \multicolumn{2}{|c|}{$\begin{array}{c}\mathrm{AEDE}_{\text {out }}\left(\mathrm{mSvy}^{-1}\right) \\
\text { For Cs } \times 10^{-3}\end{array}$} & \multicolumn{2}{|c|}{$\begin{array}{l}\text { ELCR } \times 10^{-3} \\
\text { For Cs } \times 10^{-6}\end{array}$} \\
\hline & ${ }^{226} \mathrm{Ra}^{232}{ }^{23 h},{ }^{40} \mathrm{~K}$ & ${ }^{137} \mathrm{Cs}$ & ${ }^{226} \mathrm{Ra}^{232}{ }^{23} \mathrm{Th}^{40} \mathrm{~K}$ & ${ }^{137} \mathrm{Cs}$ & ${ }^{226} \mathrm{Ra}^{232}{ }^{23 h},{ }^{40} \mathrm{~K}$ & ${ }^{137} \mathrm{Cs}$ & ${ }^{226} \mathrm{Ra}^{232}{ }^{232} \mathrm{Th}^{40} \mathrm{~K}$ & ${ }^{137} \mathrm{Cs}$ \\
\hline VS1 & 49.46 & 0.26 & 0.24 & 0.13 & 0.06 & 0.32 & 0.21 & 1.11 \\
\hline VS2 & 36.92 & N.D* & 0.18 & N.D* & 0.05 & N.D* & 0.18 & N.D* \\
\hline VS3 & 46.58 & N.D* & 0.23 & N.D* & 0.06 & N.D* & 0.21 & N.D* \\
\hline VS4 & 43.75 & N.D* & 0.21 & N.D* & 0.05 & N.D* & 0.18 & N.D* \\
\hline VS5 & 39.14 & N.D* & 0.19 & N.D* & 0.05 & N.D* & 0.18 & N.D* \\
\hline VS6 & 50.00 & 0.02 & 0.25 & 0.01 & 0.06 & 0.03 & 0.21 & 0.09 \\
\hline VS7 & 49.77 & 0.01 & 0.24 & 0.01 & 0.06 & 0.01 & 0.21 & 0.05 \\
\hline VS8 & 55.60 & 0.16 & 0.27 & 0.08 & 0.07 & 0.19 & 0.25 & 0.68 \\
\hline VS9 & 57.30 & 0.09 & 0.28 & 0.04 & 0.07 & 0.11 & 0.25 & 0.39 \\
\hline VS10 & 63.17 & 0.15 & 0.31 & 0.07 & 0.08 & 0.18 & 0.28 & 0.64 \\
\hline VS11 & 53.01 & 0.16 & 0.26 & 0.08 & 0.07 & 0.19 & 0.25 & 0.67 \\
\hline VS12 & 54.34 & 0.22 & 0.27 & 0.11 & 0.07 & 0.26 & 0.25 & 0.93 \\
\hline VS13 & 56.93 & 0.13 & 0.28 & 0.06 & 0.07 & 0.16 & 0.25 & 0.55 \\
\hline VS14 & 31.72 & 0.13 & 0.16 & 0.06 & 0.04 & 0.16 & 0.14 & 0.57 \\
\hline VS15 & 51.65 & N.D* & 0.25 & N.D* & 0.06 & N.D* & 0.21 & 0.00 \\
\hline VS16 & 60.65 & 0.10 & 0.30 & 0.05 & 0.07 & 0.13 & 0.25 & 0.45 \\
\hline VS17 & 59.90 & 0.53 & 0.29 & 0.26 & 0.07 & 0.66 & 0.25 & 2.29 \\
\hline VS18 & 61.90 & 0.18 & 0.3 & 0.09 & 0.08 & 0.23 & 0.28 & 0.79 \\
\hline VS19 & 31.72 & 0.13 & 0.16 & 0.06 & 0.04 & 0.16 & 0.14 & 0.57 \\
\hline VS20 & 67.64 & 0.30 & 0.33 & 0.15 & 0.08 & 0.37 & 0.28 & 1.30 \\
\hline mean & 51.06 & 0.13 & 0.25 & 0.06 & 0.06 & 0.17 & 0.22 & 0.55 \\
\hline
\end{tabular}

*.Not Detected

\section{DISCUSSION}

\section{Activity and statistical analysis of activity}

The range of the specific activities of ${ }^{226} \mathrm{Ra}$, ${ }^{232} \mathrm{Th},{ }^{40} \mathrm{~K}$ and ${ }^{137} \mathrm{Cs}$ for cultivated (virgin) soil samples ranged from $12.53 \pm 1.63(14.72 \pm 1.27)$ to33.03 \pm 1.79 (31.36 \pm 2.08$), 11.30 \pm 2.07$ (22.11 $\pm 1.34)$ to $37.87 \pm 1.40 \quad(50.32 \pm 3.21)$, $271.86 \pm 8.04 \quad(271.86 \pm 8.04)$ to $605.50 \pm 18.02$ $(611.61 \pm 13.85)$ and $<1.43$ to $13.36 \pm 0.89$ (17.78 \pm 0.82$)$ in Bqkg-1, $^{-1}$ respectively. The average values of corresponding radionuclides calculated as 20.81 $\pm 0.83 \quad(23.99 \pm 0.37)$, $26.99 \pm 0.38 \quad(31.74 \pm 0.38), \quad 430.34 \pm 2.74$ (461.09 \pm 2.68$), 4.26 \pm 0.14(5.51 \pm 0.14)$ in $\mathrm{Bqkg}^{-1}$, respectively. The obtained results indicate that the average specific activity $\left(\mathrm{Bqkg}^{-1}\right)$ of ${ }^{40} \mathrm{~K}$ and ${ }^{232} \mathrm{Th}$ in virgin soil samples was close to the global average, but in the case of ${ }^{226} \mathrm{Ra}$ it was lower (1).The statistical analysis of the data was performed using SPSS version 16. Using the Pearson linear regression method, the correlation coefficient $\mathrm{R}^{2}$ for radium-potassium and potassium- thorium in cultivated soil (stellar) and virgin soil (square) are shown in figure 2. The amounts of $\mathrm{R}^{2}$ (standard beta coefficient) were 0.555 and 0.864 for cultivated and virgin soils, indicating respectively a significant correlation between radium and potassium at a probability of $1 \%$. This factor shows that cultivated soil irrigation will be caused by the radium salt transferred to the deep layer. Correlation coefficients between every two different radionuclides calculated by this method are listed in table 6 . The strength of the correlation was described using a guide, which Evans (1996) suggested for the absolute value of $R^{2}$. The results showed a strong positive correlation between ${ }^{226} \mathrm{Ra}$ and ${ }^{232} \mathrm{Th}$ and very strong between ${ }^{226} \mathrm{Ra}$ and ${ }^{40} \mathrm{~K}$ with values of 0.732 (0.693) and 0.934 (0.753), respectively in the virgin (cultivated) lands. In both methods, the values of the correlation coefficient obtained the same. There is an agreement between data 
in both of them. According to the data in table 6 , the weak correlation between cesium and other radionuclides is evident because cesium as an artificial nuclide is transported by wind from other countries during nuclear accidents.

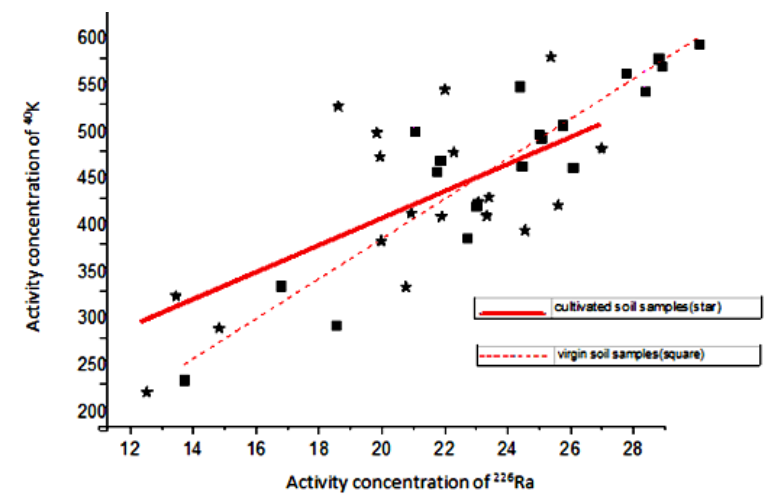

Figure 2. Variability of ${ }^{40} \mathrm{~K}$ vs ${ }^{226} \mathrm{Ra}$ activity concentration in cultivated (star) and in virgin (square) soils.

Table 6. Correlation coefficients between ${ }^{226} \mathrm{Ra}$ and other radionuclides for cultivated and virgin soil.

\begin{tabular}{|c|c|c|c|c|c|}
\hline \multirow{2}{*}{\multicolumn{2}{|c|}{ radionuclide }} & \multicolumn{4}{|c|}{ linear statistical model } \\
\hline & & \multicolumn{2}{|c|}{ regression } & \multicolumn{2}{|l|}{ Pearson } \\
\hline $\begin{array}{c}\text { independen } \\
\text { variable }\end{array}$ & $\begin{array}{l}\text { dependent } \\
\text { variable }\end{array}$ & $\begin{array}{c}\text { Standardized } \\
\text { coefficients } \\
\text { Beta }\end{array}$ & sig & $\begin{array}{l}\text { Correlation } \\
\text { coefficients }\end{array}$ & sig \\
\hline \multicolumn{6}{|c|}{ Cultivated soil } \\
\hline \multirow[t]{3}{*}{${ }^{226} \mathrm{Ra}$} & ${ }^{40} \mathrm{~K}$ & 0.633 & 0.035 & $0.633^{* *}$ & 0.004 \\
\hline & ${ }^{232} \mathrm{Th}$ & 0.619 & 0.013 & $0.619 * *$ & 0.005 \\
\hline & ${ }^{137} \mathrm{Cs}$ & 0.370 & 0.000 & 0.370 & 0.119 \\
\hline \multicolumn{6}{|c|}{ Virgin soil } \\
\hline \multirow[t]{3}{*}{${ }^{226} \mathrm{Ra}$} & ${ }^{40} \mathrm{~K}$ & 0.934 & 0.097 & $0.934 * *$ & 0.000 \\
\hline & ${ }^{232} \mathrm{Th}$ & 0.732 & 0.02 & $0.732 * *$ & 0.000 \\
\hline & ${ }^{137} \mathrm{Cs}$ & 0.385 & 0.000 & 0.385 & 0.094 \\
\hline
\end{tabular}

\section{Radiological indices}

The estimated $\mathrm{Ra}_{\mathrm{eq}}$ values range is from 51.57 to 119.8 with an average of 93.92 in $\mathrm{Bqkg}^{-1}$ in the cultivated soil samples.

The average $\mathrm{Ra}_{\mathrm{eq}}$ value for the virgin soil was 108.08 $\mathrm{Bqkg}^{-1}$ (range: 67.8-145.1). These values are lower than the permissible maximum value of $370 \mathrm{Bqkg}^{-1}$ and worldwide average (139.70). The calculated dose absorption in air at a height of 1 meter above the ground for samples is from 24.49 to 56.30 , with average values of 44.57 and 51.06 respectively in $\mathrm{nGyh}^{-1}$. In samples of cultivated and virgin soil, these values were lower than worldwide average as 55 nGyh $^{-1}$ (1).The mean value of absorbed dose in air due to ${ }^{137} \mathrm{Cs}$ was calculated, respectively, 0.11 and 0.13 in nGyh $^{-1}$. The AEDE indoor absorbed by an adult due to natural and artificial radionuclides ranged from 0.12 to 0.28 , and ND to $1.44 \times 10^{-3}$,

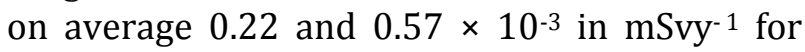
cultivated soils, while the average of this index for outdoor was 0.05 and $1.22 \times 10^{-4} \mathrm{mSvy}^{-1}$, respectively. The ranges of AEDE indoor due to natural and artificial radionuclides in virgin soil were calculated as $0.16-0.33$ and ND-2.61× $10^{-3}$ in $\mathrm{mSvy}^{-1}$ with average values of 0.25 and $0.63 \times$ $10^{-3} \mathrm{mSvy}^{-1}$, respectively, while the average of this index for outdoor is 0.06 and $1.67 \times 10^{-4}$ $\mathrm{mSvy}^{-1}$. The average global value is $0.48 \mathrm{mSvy}^{-1}$, of which $0.07 \mathrm{mSvy}^{-1}$ comes from outside and $0.41 \mathrm{mSvy}^{-1}$ from indoor (1). Therefore, the area does not pose a threat to the population. The average annual dose of ${ }^{137} \mathrm{Cs}$ gamma radiation for all samples is less than the reported 0.6 $\mathrm{mSvy}^{-1}$ values by the United Nations Scientific Committee on the effects of atomic radiation (1). The external hazard index deals with the assessment of excess gamma radiation from radionuclides in cultivated or virgin soils. Average $H_{\text {in }}$ and $H_{\text {ex }}$ values for cultivated (virgin) soils samples obtained as $0.31(0.35)$ and 0.25 (0.29) respectively, which are lower than the maximum allowable limit (1). In the case of virgin soil, the indicators of external and internal threats are higher than that of cultivated land, which shows that radium and thorium salts can be transported to deeper layers by irrigation. The index of $\mathrm{I}_{\gamma}$ is ranged from 0.39 to 0.89 and from 0.03 to 1.07 , with an average value of 0.68 and 0.73 for the cultivated and virgin soil samples, which for most of them are less than one value. Table 5 lists the specific activities of natural radionuclides in cultivated and primary soils of some countries, which shows that in Pakistan, Turkey, Bangladesh and Malaysia are higher and for other countries are in the same range. Distribution maps of ${ }^{226} \mathrm{Ra}$, ${ }^{232} \mathrm{Th}$ and ${ }^{137} \mathrm{Cs}$ in Fig. 3 for cultivated land were plotted using the SURFUR software version 15, which shows that the ${ }^{226} \mathrm{Ra}$ and ${ }^{137} \mathrm{Cs}$ distributions are similar. Since the distribution of ${ }^{137} \mathrm{Cs}$ depends on the wind and the

Int. J. Radiat. Res., Vol. 18 No. 4, October 2020 
topography of the area, these maps show that part of the radium is dispersed in environments by fly ash from the outlet of the chimneys of refinery by the wind. The excess lifetime cancer risk (ELCR) was obtained for cultivated (virgin) soil as $0.19 \times 10^{-3}\left(0.22 \times 10^{-3}\right)$, which is in the range to the world average $\left(0.29 \times 10^{-3}\right)$ and is

Table 7. Comparison of the average activity of natural radionuclides in Bqkg-1 for some countries.

\begin{tabular}{|c|c|c|c|c|}
\hline country & ${ }^{238} \mathrm{Ra}$ & ${ }^{232} \mathrm{Th}$ & ${ }^{40} \mathrm{~K}$ & reference \\
\hline \multicolumn{4}{|c|}{ cultivated soil samples } & \\
\hline Syria & 23 & 20 & 270 & $(1)$ \\
\hline Oman & 29.7 & 15.9 & 225 & $(2)$ \\
\hline Pakistan & 73.9 & 152.2 & 325.3 & (16) \\
\hline Turkey & 85.75 & 51.08 & 771.57 & (19) \\
\hline $\begin{array}{c}\text { Iran(Arak and } \\
\text { Sareband) }\end{array}$ & 45.54 & 69.09 & 926.71 & (20) \\
\hline Iran & 20.81 & 26.99 & 430.43 & This work \\
\hline \multicolumn{4}{|c|}{ virgin soil samples } & \\
\hline Bangladesh & 60.2 & 60.8 & 928 & $(21)$ \\
\hline china & 38 & 57.6 & 838 & $(22)$ \\
\hline Malaysia & 51.06 & 78.44 & 125.66 & $(23)$ \\
\hline Turkey & 115 & 192 & 1207 & (24) \\
\hline Nigeria & 18 & 22 & 210 & $(25)$ \\
\hline Botswana & 34.8 & 41.8 & 432.7 & $(26)$ \\
\hline Yemen & 44 & 58 & 822 & $(27)$ \\
\hline $\begin{array}{c}\text { Iran(Arak and } \\
\text { Sareband) }\end{array}$ & 37.27 & 43.18 & 604.05 & (20) \\
\hline Iran & 23.99 & 31.74 & 461.09 & This work \\
\hline
\end{tabular}

\section{CONCLUSION}

- Average activity concentration of radionuclides ${ }^{226} \mathrm{Ra},{ }^{232} \mathrm{Th},{ }^{40} \mathrm{~K}$ and ${ }^{137} \mathrm{Cs}$ were measured which lies within the world range values in cultivated (virgin) soil samples.

- All soil samples were polluted by ${ }^{137}$ Cs which indicate the pollution this region by radioactive dust originated from other countries.

Int. J. Radiat. Res., Vol. 18 No. 4, October 2020

less than the permissible value $\left(10^{-3}\right)$. Table 7 provides a comparison of the average activity of natural radionuclides in $\mathrm{Bqkg}^{-1}$ for some countries, which show that in Pakistan (16), Turkey (19,24), Bangladesh (22), and Malaysia (23), are higher and for other countries are in the same range.
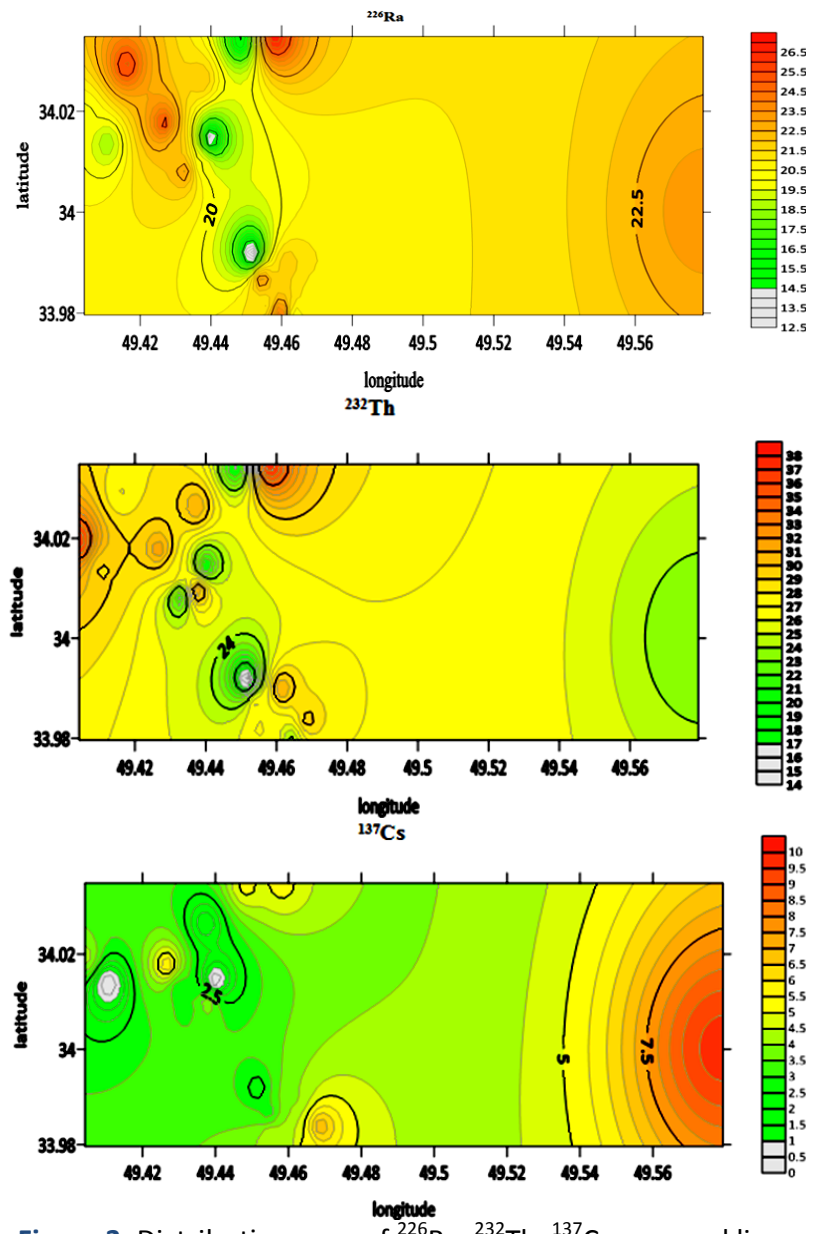

Figure 3. Distribution map of ${ }^{226} \mathrm{Ra},{ }^{232} \mathrm{Th},{ }^{137} \mathrm{Cs}$ on equal lines in cultivated studied regions (X-axis; longitude (E-W (Deg)), Y-axis: latitude(S-N (Deg))).

- The average activity concentrations of the measured radionuclides in the virgin soils were higher than the cultivated soils, which may be due to the irrigation of the area during cultivation and the transfer of their salts to deeper layers.

- All calculated radiological parameters are within acceptable limits and do not threaten the dangers of the population living in this area. 


\section{ACKNOWLEDGEMENTS}

The authors thank the research department of Arak University for financing this study.

\section{Conflicts of interest: Declared none.}

\section{REFERENCES}

1. UNSCEAR United Nations Scientific Committee on the Effects of Atomic Radiation (2008) in sources and effects of ionizing radiation report to general assembly with scientific Annexes. New York, United Nation Publication

2. Goddard CC (2001) Measurement of Outdoor Terrestrial Gamma Radiation in the Sultanate of Oman. Journal Health Physics, 82(6): 869-74.

3. Egunyinka OA, Olowookere CJ, - Babalo IA, Obed RI (2009) -- Evaluation of U-238, Th-232, K-40 concentrations in the top soil of the University of Ibadam South -Western Nigeria. Pacif. Journal of Science Technology, 10 (2): 742-750.

4. Firestone B R, Shirley SV, Baglin MC, Frank, Chu SY, Zipkin J (1996) The composition of the continental crust. International journal of New Geochemical Cosmo chimical acta, 59: 217-239.

5. Kolb WA and Wojacik M (1985) Enhanced radioactivity due to natural oil and gas production and related radiological problems. Science of the Total Environment, 45: 7784.

6. Al-Farsi AN (2008) Radiological Aspects of Petroleum Exploration and Production in the Sultanate of Oman. Ph.D. Dissertation, Queensland University of Technology, Australia.

7. Igarashi $\mathrm{Y}$, Otsuji-Hatori $\mathrm{M}$, Hirose $\mathrm{K}$ (1996) Recent deposition of ${ }^{90} \mathrm{Sr}$ and ${ }^{137} \mathrm{Cs}$ observed in Tsukuba. Journal of Environmental Radioactivity, 31: 157-169.

8. History of Shazand Petrochemical Company. (2012) available from: https://www.arpc.ir/Default.aspx? tabid=330\&language $=$ en - US

9. Jibiri NN and Esen NU (2011) Radionuclide contents and radiological risk to the population due to raw minerals and soil samples from the mining sites of quality ceramic and pottery industries in Akwa Ibom, Nigeria. Journal of Radiation protection dosimetry, 46(1): $75-87$.

10. Aziz A (1981) Methods of Low-Level Counting and Spectrometry Symposium, 221. Berlin

11. Luminita A, Michael W, Andrew E, Wei H (2015) Proficiency study AQA 15-14 metals and anions in soil. Australian Government National Measurement Institute.

12. International Atomic Energy Agency (2003) Collection and preparation of bottom sediment samples for analysis of radionuclides and trace elements. IAEA-TECDOC-1360, IAEA; VIENNA.

13. Šostaric M, Petrinec B, Babic D (2013) ${ }^{137}$ Cs in soil and fallout around Zagreb (CROATIA) at the time of the Fukushima accident. Archives of Industrial Hygiene and Toxicology, 64(4): 561-5.

14. Currie LA (1968) Limits for qualitative detection and quantitative determination. Journal of Radioanalytical Nuclear Chemistry, 40(3): 586-593.

15. EC (1999) European Commission Report on Radiological Protection Principles Concerning the Natural Radioactivity of Building Materials. Radiation Protection, 112: 1-16.

16. Rahman SU, Matiullah MF, Rafique M, Anwar J, Ziafat, M, Jabbar A (2011) Measurement of naturally occurring fallout radioactive elements and assessment of annual effective dose in soil samples collected from four districts of the Punjab Province, Pakistan. Journal of Radioanalytical and Nuclear Chemistry, 287: 647-655.

17. Tufail M, Akhtar N, Jaried S, Hamid T (2007) Natural radioactivity hazards of building bricks fabrication from soil of two districts of Pakistan. Journal of Radiological Protection, 27: 481-492.

18. ICRP Publication 119. Compendium of dose coefficient based on ICRP Publication 60. 2012; 41(1).

19. Dizman S, Görür FK, Keser R (2016) Determination of radioactivity levels of soil samples and the excess of lifetime cancer risk in Rize province,Turkey. Int I Radiat Res, 14(3): .244-237

20. Pourimani $R$ and Yousefi $F$ (2017) Investigation of natural radioactivity of agricultural and virgin soils in Arak and Saraband cities in central province, Iran. Journal of Water and soil, 31(5): 1371-1382.

21. Alam MN, Miah MMH, Chowdhury MI, Kamal M, Ghose S, Islam MN, Mustafa MN, Miah MSR (1999) Radiation dose estimation from the radioactivity analysis of lime and cement used in Bangladesh. Journal of Environmental Radioactivity, 42: 77-85.

22. Ziqiang $P$, Yin $Y$, Mingqiang $G$ (1988) Natural radiation and radioactivity in China. Journal of Radiation Protection Dosimetry, 24: 29-38.

23. Nisar A, Suhaimi JM, Alsaffar MS (2015) Natural radioactivity in virgin and agricultural soil and its environmental implications in Sungai Petani, Kedah, Malaysia. Pollution, 1 (3): 305-313.

24. Merdanoğlu B and Altınsoy N (2006) Radioactivity concentrations and dose assessment for soil samples from Kestanbol granite area, Turkey. Journal of Radiation Protection Dosimetry, 121: 399-405.

25. Agbalagba E and Onoja R (2011) Evaluation of natural radioactivity in soil, sediment and water samples of Niger Delta (Biseni) flood plain lakes, Nigeria. Journal of Environmental Radioactivity, 102: 667-671.

26. Murty V and Karunakara N (2008) Natural radioactivity in the soil samples of Botswana. Journal of Radiation Measurement, 43: 1541-1545.

27. Abd El-mageed Al, El-Kamel AH, Abbady A, Harb S, Youssef AMM, Saleh II (2011) Assessment of Natural and Anthropogenic Radioactivity Levels in Rocks and Soils in the Environments of Juban Town in Yemen. Radiation Physics and Chemistry, 80(6): 710-715.

Int. J. Radiat. Res., Vol. 18 No. 4, October 2020 